\title{
Lexicography in Australia
}

\section{A. Delbridge, Macquarie University, New South Wales, Australia}

Abstract: This paper describes the current setting for lexicography in Australia by reviewing the place of English since the first British settlement began in 1788. The emergence of Australian English as the national language is traced, and its relations with the Australian Aboriginal languages touched on. The greatest change in the language selting came with Australia's immigration policy in its post-World War 11 form. This resulted in the government's eventual recognition of Australia as multilingual and multicultural, and urgently in need of a formal policy on languages, one which treated the many community languages of Australia as an economic, social, educational asset.

The paper then summarises the past and present record of lexicography, in Australian English, in Aboriginal and community languages, and in languages of its neighbours in the Pacific area. Titles of some of the most important dictionaries are listed in the bibliography.

It ends by describing the outlook of the newly formed Australasian Association for Lexicography.

Keywords: LEXICOGRAPHY, AUSTRALIAN ENGLISH, ABORIGINAL LANGUAGES, COMMUNITY LANGUAGES, IMMIGRATION, NATIONAL LANGUAGE POLICY, MULTICULTURAL, BILINGUAL, COLLOQULALISM, AUSTRALIANISM, DATABASE, CORPUS, AUSTRALEX

Opsomming: Leksikografie in Australië. Hierdie bydrae beskryf die huidige leksikografiese situasie in Australië deurdat daar 'n oorsig gegee word van die situasie van Engels sedert die eerste Britse vestiging in 1788. Die opkoms van Australiese Engels as nasionale taal word nagespoor, en die Australiese inboorlingtale word aangeroer. Die grootste verandering in die taalsituasie het plaasgevind as gevolg van Australië se immigrasiebeleid na die Tweede Wêreldoorlog. Dit het daartoe gelei dat die regering Australië uiteindelik as 'n multitalige en multikulturele land begin sien het. Die regering het ook die dringende behoefte aan ' $n$ formele taalbeleid, wat die onderskeie gemeenskapstale van Australië as ekonomiese, sosiale en opvoedkundige bate sou hanteer, begin besef.

Daama word die vorige en huidige leksikografiese situasie in Australiese Engels, in inboorling- en gemeenskapstale, sowel as in tale van die Stille Oseaan-gebied in hierdie bydrae geskets. Titels van sommige van die belangrikste woordeboeke word in die bibliografie gelys.

Hierdie stuk eindig met ' $n$ beskrywing van die uitgangspunte van die nuutgestigte Australasian Association for Lexicography.

Sleutelwoorde: LEKSIKOGRAFIE, AUSTRALIESE ENGELS, INBOORLINGTALE, GEMEENSKAPSTALE, IMMIGRASIE, NASIONALE TAALBELEID, MULTIKULTUREEL, TWEETALIG, SPREEKTAALUITDRUKKING, AUSTRALIËNISME, DATABASIS, KORPUS, AUSTRALEX 


\section{LEXICOGRAPHY IN AUSTRALIA}

Should a history of lexicography in Australia ever be written, it would be apparent from it that until about twenty-five years ago Australians assumed that somebody else should write dictionaries for them, that this monolingual community (except for its students) needed only dictionaries of English, and that what Oxford or Websters produced in this line for international distribution would meet Australian needs perfectly well, indeed might even help to keep Australian usage from straying shamefully far from the requirements of Standard English. Yet such assumptions have by now been so radically called into question that an academic proposal to establish a national association of lexicographers has been implemented, and the resulting Australasian Association for Lexicography is now well into the second year of its initial program, with some 150 members, including lexicographers, publishers, editors, linguists and interested members of the public.

\section{THE CURRENT SETTING FOR AUSTRALIAN LEXICOGRAPHY}

Nothing testifies to the need for dictionaries made in Australia more directly than the diversity of language and culture in its population. This diversity is the product of immigration: only the Australian Aboriginal people can claim not to be immigrants. The First Fleet brought its cargo of convicted felons from England in 1788, to serve out their sentences in New South Wales, many of them never to return. They brought many varieties of English with them, with those of London English predominating. But the experience of adapting to the social and physical novelties of life in the antipodes under the convict system soon changed these transported dialects into a relatively homogeneous and distinct variety of English. By the second or third decade of the nineteenth century the language of the colony was noticeably distinctive in vocabulary and accent. And after more than a hundred years of further lexical and phonological development it got itself cautiously recognised by Australians as Australian English. But not until the middle of this present century! Although (Australian) English has never been declared the country's official language, it is certainly the national language, the mother-tongue of the majority of nativeborn Australians, the language of government, of law, of the workplace, the language for all Australians.

Yet English is only one of at least 250 languages now in use in Australia. Some of them are Aboriginal languages, others the so-called "community languages" brought here by immigrants (the usual Australian word is migrants) from the middle of the nineteenth century and on, but particularly since World War II. In the 1986 Census of Population and Housing the total population of Australia was recorded as $15,602,156$ persons, and 13.63 per cent of these indicated that they used a language other than English at home. 
If one compares the 1986 Census figures with those of 1901, the year in which the various state colonies became federated into the Commonwealth of Australia, it is evident that the proportion of those born in Australia stands the same in both, that is, at 77 per cent. In 1901, all but 5\% of the remainder had been born in England, Wales, Scotland or Ireland, speaking some variety of English. At this time the prevailing mood was strongly nationalist, with the young nation determinedly monolingual, as a token both of its British tradition and allegiance, and of its sense of national identity. But in 1986, 8.8\% declared that they were born in other English-speaking countries, and $12.2 \%$ that they were born in non-English speaking countries.

The growing pluralism implicit in these percentages has always had to face some level of conflict with the entrenched notion of a single culture, a single language. For the first half of this century, it was expected of migrants that they would assimilate to "the Australian way of life", and there was no encouragement given to language maintenance among non-English-speaking migrants. But for the past twenty years new attitudes have been developing: "assimilation" has been replaced by "integration", migration from Asia has become an important part of government policy, and the presence of "community languages" seen as a positive asset to be nurtured and developed. In 1978 Malcolm Fraser, the then Prime Minister, declared that "Australia is at a critical stage in developing a cohesive, united, multicultural nation .... [The government] will foster the retention of the cultural heritage of different ethnic groups and promote intercultural understanding."

The development of Australia's multicultural policy, from the early 1970's on, has inevitably led to the discussion in the national government of the need for a policy on languages. This discussion was driven by a growing sense of the importance, in what had been essentially a monolingual country, of making a positive asset out of our greatly increased multilingualism. Australian politics, economics, and education were deeply implicated in the direction these discussions might take, as indeed was the sense of national identity. Because the immigrant population was not spread evenly among the various states of the Commonweal th, there was a need for co-ordination of language policies at a national level which would give full consideration to the experience of those states in which the problems and opportunities were already being most fully explored. In Victoria, for example, there was a rather heavy concentration of Greek and Italian migrants, and by 1979, without special reference to any particular community languages, the Victorian Education Department announced a policy with three leading principles:

i. All citizens should be proficient in English;

ii. Children should have the opportunity to learn the language and cultures of their forbears; 
iii. All should have the opportunity to study other languages and cultures, particularly those represented in the population. (Shears 1979)

But it was not only state bodies that contributed to the national discussion. There were submissions from the Australian Institute of Multicultural Affairs, the Australian Ethnic Affairs Council, the Applied Linguistics Association of Australia, the Australian Linguistics Society, the Australian Federation of Modern Language Teachers Association, the Aboriginal Language Association, and many others, eventually combining their efforts as the Professional Language Associations for a National Language Policy. The culmination of these wide-spread efforts came with the release in 1987 of the National Policy on Languages,' a report written by lo Bianco, an applied linguist, whose recommendations were based on the following justifications: social justice, enrichment for all Australians, economic strategies, and Australia's external relationships.

His recommendations, soon to be implemented nationally, were:

* English for all

* $\quad$ support for Aboriginal and Torres Strait Island languages

* a language other than English for all (through both mother-tongue maintenance and second language learning)

* equitable and widespread language services.

In 1988 the Federal Government set up the Australian Advisory Council on Languages and Multicultural Education, and in 1990 a National Languages Institute, responsible for establishing a number of administrative and research centres around Australia to co-ordinate the implementation of the national objectives, and facilitate the sharing of the so far generous resources assigned by the Government.

Summarising his account of community languages in Australia, Michael Clyne, Australia's leading sociolinguist, expressed the view that "Australia is unique beside comparable nations - first, because it has a National Policy on Languages; and second, because of the complementarity of English and other languages in its policies." (Clyne 1991a: 245)

\section{THE LEXICOGRAPHIC RECORD}

\section{Australian English}

Although there were commentaries enough throughout the nineteenth century on how the colonial settlements of Australia were adapting their transported English to the physical and social realities of life here, there was no lexicography worthy of notice until 1889 . In that year two dictionaries were published. 
J.A. Lake prepared his Dictionary of Australian Words as a supplement to Webster's International Dictionary (1889), and E.E. Morris, having gathered substantial material for his contribution to the Oxford English Dictionary, using the historical principles of that work, then published it as a dictionary of his own under the title Austral English. In it he recorded "all the new words and the new uses of old words that have been added to the English language by reason of the fact that those who speak English have taken up their abode in Australia, Tasmania and New Zealand". Unlike the earlier commentators who gave primary attention to what they regarded as Australian slang, Morris concentrated on the core of Australian nomenclature, including: names of flora and fauna; English words used in distinctively Australian senses; words taken from native languages of the regions; fanciful, picturesque, or humorous names given to local natural objects; new coinages; new scientific names; and slang (of which, he says, "the element is comparatively small"). All the entries are supported by citations from Australian texts, with sources and dates in the Oxford style.

The name "Austral English" was an early first shot at a concept which over the next 50 years was found by serious observers of English in Australia to be both attractive and necessary, but by the population at large as a device for robbing them of their right to the Cultural Cringe, deeply felt in language as in other aspects of social life. ("The core of the difficulty", wrote Phillips, who invented the term in 1950, "is the fact that, in the back of the Australian mind, there sits a minatory Englishman.") (Phillips 1950)

It was not until the 1940's that the term "Australian English" came into tentative use to describe the national variety of English. But when at that time Professor A.G. Mitchell, who did so much to promote the serious study of that variety, wrote a popular broadcast for national radio with the title "There is Nothing Wrong with Australian Speech", it was greeted with almost universal hostility. Such was the readiness of Australians to acknowledge their own language!

In the meantime there had been precious little lexicography. The dictionaries in public and private use were mainly from British publishers (Oxford, Chambers, etc.), and rather less from American. None from Australian, and certainly none that focussed on Australian usage. This was in spite of the fact that there had been a good deal of serious study of Australian lexis (See Baker 1945, and Ramson 1966). The Australian Language Research Centre, established in Sydney University, produced a number of occasional papers on aspects of Australian vocabulary, but no dictionary. In 1976 Oxford University Press Australia issued an Australianised version of the Pocket Oxford Dictionary, edited by Graham Johnston, in which words believed to be distinctively. Australian were labelled Austral. But still no comprehensive dictionary appeared, comparable with, say, even the Concise Oxford Dictionary of Current English or the American College Dictionary, no book for the hands of people seriously wanting to consult Australian lexical usage. 
But since then there have been at least three major publications which between them have filled the lexicographic gap. These are a Dictionary of Australian Colloquialisms (Wilkes 1978), The Macquarie Dictionary (Delbridge 1981), and The Australian National Dictionary (Ramson, 1988).

Before Wilkes, there had been a number of more minor attempts to present Australian slang and colloquialism as the most striking and distinctive aspect of Australian English, and even as a distinctive trait in the national character. Our novelists of social realism had tended to foreground slang in dialogue, in the portrayal of their personae. Wilkes's dictionary is drawn largely but not exclusively from Australian fiction (he held the chair of Australian Literature in Sydney University while he was writing it). But it is a wellbalanced account, making no exaggerated claims for the quality of Australian colloquialism. Its historical method, with generous dated citations, gives a solid basis for conclusions about the period of currency of the headwords and the development of their various senses. A revised edition appeared in 1985.

The Macquarie Dictionary $(1981,1991)$ was intended to be the first Australian dictionary to offer a comprehensive word list in which all the pronunciations, all the spellings, and all the definitions of meaning are taken from the use of English in Australia, and in which Australian English becomes the basis of comparison with other national varieties of English. It was hoped that no longer would Australians wishing to consult the usage of their own community find that the only available dictionaries were focussed on the usage of communities in the northerm hemisphere. These hopes have been realised, and there is now a wide-spread perception of the Macquarie as the first-port-of-call dictionary for Australian users. It has been adopted by many organisations in government, in education, in broadcasting and in journalism, and is frequently quoted in the courts of law and in the press. In the second edition there are more than 300,000 vocabulary items and definitions derived from a large computer database, with special attention given to new words of the eighties, whether of local coinage or drawn into local usage from other varieties of English or other languages. Variation in usage has been the subject of intense study in the preparation of this edition, and the entries reflect the work of five annual Style Councils convened by the Dictionary Research Centre of Macquarie University, and attended by publishers, lawyers, educationists, lexicographers, editors, specialists in computing, and others with professional interests in style in language. Macquarie Library Pty. Ltd., publisher of the Macquarie Dictionary, have also published a number of spin-off dictionaries drawn from the same large database. These include a companion thesaurus, edited by J.R.L. Bernard (1984), and sets of dictionaries and thesauruses of different sizes, for users with different educational needs, with twenty volumes now in print.

The Australian National Dictionary was published in 1988 by Oxford University Press Australia. Its editor, W.S. Ramson, of the Australian National University, Canberra, is a leading figure in the study of the history of 
Australian English. It is a dictionary of Australianisms written on the same historical principles as the Oxford English Dictionary, with its entries drawn from the close reading of nearly 10,000 books and papers with Australian associations, wherever published. The dictionary consists of about 6,000 main entries, each of which treats a word or phrase judged to be distinctively Australian. The generous provision of citations establishes the chronology of each word's use, substantiates the definitions, and illustrates the range of registers within which it has been used. It is the first historical dictionary of the whole language since Morris, and the only comprehensive one. There were difficulties, of course, in establishing strong claims for an Australian origin for many words, even with citations that antedated those of British or American dictionaries. It therefore seemed best to the editor to interpret Australianism liberally, "not making undue claims but including many words which are of undoubted significance in the Australian context but about the precise origin of which there remains uncertainty." Some 400 borrowings from Aboriginal languages are recorded, and for the first time in Australian lexicography, the etymologies in most cases identify the source language, a reflection of the advanced state of the present knowledge of the over 200 Aboriginal languages that had been in use at the time of the first European settlement, when Aboriginal contact was lexically most productive. The Australian National Dictionary has become an indispensible tool for historians and literary scholars, as well as a source of interest in the general population, for the latter notably in its concise format edited by Joan Hughes (Hughes, 1989).

\section{Australian Aboriginal Languages}

The Aboriginal languages have been under severe pressure ever since the first European settlement was founded in 1788. Many of the original languages have become extinct, and in many of the present-day communities a language shift to English or an English-based creole is under way. Only about fifty languages remain with viable speech communities, with another hundred still spoken by one or more individuals. In the past twenty years there has been a very considerable acceleration in the scholarly study of these languages and their remnants, in Australia and in other parts of the world.

During the 1980's Aboriginal people themselves have been increasingly trained in research methods, mainly in the School of Australian Linguistics in the Northern Territory, and there have been a number of research publications by Aboriginal linguists on their own languages. (Austin 1991)2

But until recently there has been a marked preoccupation with grammar: in the 1980's the grammars of twenty-one languages were published, and thirteen others completed but not published. In Austin's view, "the study of word meaning and the preparation of dictionaries of Australian Aboriginal languages has remained a poor cousin of grammatical description" (Austin 1991: 
59). The number of published dictionaries is small compared to the number of grammars, and some of them are confessedly word lists. Typically they are bilingual, with English the target language, and with lexical information concentrated in the Aboriginal-English section of the lists.

But there are now several major lexicographical projects current, with sample entries already published and lively debate ensuing over the methodology employed. In 1987 the Australian Institute of Aboriginal Studies established its National Lexicography Project. One major publication to emerge from its work is a collection of Aboriginal wordlists on a national scale, to be published by Macquarie Library Pty. An objective of this publication is to better inform the general Australian community of the richness and diversity of the indigenous languages and of the life of the people who use them.

\section{Community Languages}

The social face of Australia has certainly been changed, especially over the last thirty years, by the presence here of migrants who are native speakers of languages other than English. Their contact with Australian English may result in anglicisation of their native language, and its attrition following a shift to English. Not surprisingly, there has been enormous academic interest in these processes of change, and many papers have been written describing Australitalian, or Australians of Macedonian origin and their speech, or Das Barossadeutsch, or Australian Polish, or Melbourne Spanish. ${ }^{3}$ Multilingual Australia offers a rich field of study not only of contact between particular languages, but of theoretical models of language contact and bilingualism.

But the interest for lexicographers is not so pressing. A few words from Vietnamese, Greek, Chinese, Italian etc. have come into Australian English from the presence of speakers of these languages here in Australia, as well as from elsewhere in the world, and they can be expected to show up in the local English dictionaries. But the anglicisation of community languages, in phonology, grammar, vocabulary and semantics, is more likely to be dealt with in papers and monographs than in dictionaries. Whatever the community need may be for bilingual dictionaries involving a community language and Australian English, there are economic reasons why they have so far not appeared in print. With the total population of Australia barely reaching sixteen million, it was a hazardous business venture to launch the monolingual Macquarie Dictionary in 1981 even in the expectation that it would be welcomed, and perhaps steal some sales from the international publishers, whose worldwide distribution systems could in any case buffer them against an Australian loss. But to publish a bilingual dictionary and attract sales among a tiny percentage of the Australian population, with no expectation of sales elsewhere in the world, could not make good economic sense. 
Here it may be said, leaving community languages aside for the moment, that Australia's position in the Pacific has naturally excited the interest of its field workers and scholars in Papuan, Austronesian and Polynesian languages to the point where their contributions in the form of learned papers, language atlases, grammars and dictionaries form a major part of the international literature on this vast area.

\section{AUSTRALEX AND THE LEXICOGRAPHIC CHALLENGE}

The Australasian Association for Lexicography (AUSTRALEX) was established in September 1990 to foster scholarly and professional activities in the field of lexicography, membership being open to any person or institution interested in the purpose of the association.

The intention is to facilitate the exchange of information and ideas through meetings, publications, and such other means as its members deem appropriate.

The first act of the executive was to initiate a newsletter and draw up a register of the lexicographic activities and interests of the members, whether individual or institutional, the details to be stored in a database and released on request. The newsletter also gives notice of conferences, linguistic institutes, specialised courses and workshops, wherever held, and sets out the development plans proposed by the executive committee. For example, it seemed that AUSTRALEX might usefully take a leading part in establishing a collaborative project in Australian English for the making of a multi-millionword national corpus. Already the Dictionary Research Centre at Macquarie University had made a small structured corpus of current Australian English, for its studies in the style of Australian usage; and Macquarie Library Ltd had produced a corpus of about 13 million words drawn from representative texts of Australian literature. The National Dictionary Centre in the Australian National University has also secured funds for preliminary studies for a large corpus. So AUSTRALEX is inviting other parties to express interest in a collaborative project. In the meantime the Federal government has made a grant of $\$ 100,000$ a year to Macquarie University through the National Languages Institute of Australia for both of these dictionary centres to further the study of Australian English as the national language of Australia. With two national conferences of lexicographers already held, and others planned, AUSTRALEX has no doubts as to its role in the development of language studies and services in Australia.

\section{Notes}


2 For this section of the paper the author has drawn heavily on Austin's review of Australian Aboriginal languages in Ch. 4 of Clyne 1991b.

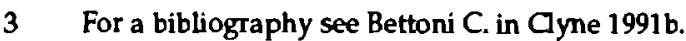

\section{References}

Austin, Peter. 1991. Australian Aboriginal Languages. Clyne, Michael (Ed.). 1991b: 55-74.

Baker, Sidney J. 1945. The Australian Language. Sydney: Angus and Robertson.

Bemard, J.R.L. (Ed.). 1984. The Macquarie Thesaurus. Sydney: Macquarie Library.

Bettoni, Camilla. 1991. Other Community Languages. Cyne, Michael (Ed.). 1991b: 75-90.

Clyne, Michael. 1991a. Community Languages: The Australian Experience. Monash University and National Languages Institute of Australia. Melbourne: Cambridge University Press.

Clyne, Michael. (Ed.). 1991b. Linguistics in Australia: Trends in Research. Canberra: Academy of the Social Sciences in Australia.

Delbridge, A., J.R.L. Bemard, D. Blair, P. Peters and S. Butler. (Edd.). 1991. The Macquarie Dictionary. (Second Edition). Sydney: Macquarie Library.

Hughes, Joan. 1989. The Concise National Dictionary. Melboume: Oxford University Press Australia.

Johnston, Graham. 1976. Pocket Oxford Dictionary. Melboume: Oxford University Press Australia.

Lake, J.A. 1898. A Dictionary of Australian Words. (Supplement to Webster's International Dictionary 1898.)

lo Bianco, J. 1987. National Policy on Languages. Canberra: Australian Government Publishing Service.

Morris, E.E. (Ed.). 1898. Dictionary of Austral English. Reissued 1972 Sydney University Press. London: Macmillan.

Phillips, A.A. 1950. The Cultural Cringe. Meanjin 9: 299-302.

Ramson, W.S. 1966. Australian English: An historical Study of the Vocabulary 1788 - 1898. Canberra: Australian National University Press.

Ramson, W.S. (Ed.). 1988. The Australian National Dictionary: A Dictionary of Australianisms on Historical Principles. Melboume: Oxford University Press.

Shears, L. 1979. This is Our Position. News Exchange, Melbourne, 14 March 1979, 3.

Wilkes, G.A. 1985. A Dictionary of Australian Colloquialisms. (Revised Edition). Sydney: Sydney University Press. 